\title{
全身麻酔中に気管支痙攣と肺高血圧を伴う 薬剤性アナフィラキシーが疑われた肺リンパ脈管筋腫症の1例
}

\author{
明賀翔平 ${ }^{* 1}$ 日笠友起子*2 岡原修司 ${ }^{* 1}$ \\ 川瀬宏和 ${ }^{* 2}$ 小林 求 $^{* 1}$ 森松博史 ${ }^{* 1}$
}

[要旨］症例は 49歳, 女性. 肺リンパ脈管筋腫症に対して脳死両肺移植が予定された. 麻酔導入後 にセフォチアムを投与したところ, 突然換気困難となり, 同時に肺動脈圧の上昇を認めた. アナフ イラキシーによる気管支痓攣を疑いアドレナリンを投与すると, 換気は改善し肺動脈圧も低下した. 全身麻酔中のアナフィラキシーは皮膚症状, 循環症状, 呼吸症状を認めることが多いが, 肺動脈圧 の変化については知られていない. 動物実験ではアナフィラキシー発症時の肺血管抵抗の上昇, 肺 高血圧が報告されているが，ヒトでの報告はこれまでにほとんどない. 本症例では, アナフィラキ シーによる気管支痙攣時に, 急激に肺高血圧を呈している可能性が示唆された.

キーワード : 全身麻酔, アナフィラキシー, 気管支痤攣, 肺高血圧

\section{はじめに}

全身麻酔中のアナフィラキシーは，報告によって 差はあるが10,000〜 20,000症例に 1 例の頻度で発生 しているといわれている ${ }^{1)}$.アナフィラキシーでは しばしば急激な気管支痤攣が起こることはよく知ら れているが，その際の肺動脈圧 (pulmonary arterial pressure : PAP)の変化については知られていない. われわれは，抗菌薬投与直後にアナフィラキシーを 疑う気管支痤攣が発生した際に，急激なPAPの上 昇を認め，アドレナリン投与により気管支痤攣が改 善し，それに伴いPAPも迅速に低下した症例を経 験したので報告する。

\section{I 症 例}

49 歳の女性で身長 $158 \mathrm{~cm}$, 体重 $34.1 \mathrm{~kg}$. 肺リン

${ }^{* 1}$ 岡山大学病院麻酔科蘇生科

*2 岡山大学病院集中治療部

$\begin{array}{lll}\text { 受付日 } & 2019 . & 9.30 . \\ \text { 受理日(採択日) } & 2020 . & 1.20 .\end{array}$
パ脈管筋腫症 (lymphangioleiomyomatosis：LAM) に対して緊急での脳死両肺移植術が予定された。既 往歴に左右の気胸があり，それぞれ胸腔鏡下肺切除 術，保存的加療を行われていた。術前に喘息の既往 はなかった。問診で過去にセフポドキシムで皮疹が あったというが，詳細は不明であった。術前検査で は，動脈血液ガス分析で $\mathrm{PaO}_{2} 67.8 \mathrm{mmHg}\left(\mathrm{O}_{2} 2 \mathrm{~L} /\right.$ min), $\mathrm{PaCO}_{2} 45.4 \mathrm{mmHg}$ と, 酸素化能低下と二酸 化炭素の軽度貯留を認めた。胸部 CT 検査では, 両 肺に著明な気腫性変化を認めた(図1)。術前の経胸 壁心エコー検査では右心負荷所見はなく，肺高血圧 症の所見は認めなかった。

\section{II 麻酔経過}

麻酔導入前に右橈骨動脈に動脈圧ラインを確保 し，麻酔導入はフェンタニル $500 \mu \mathrm{g}$, ミダゾラム 


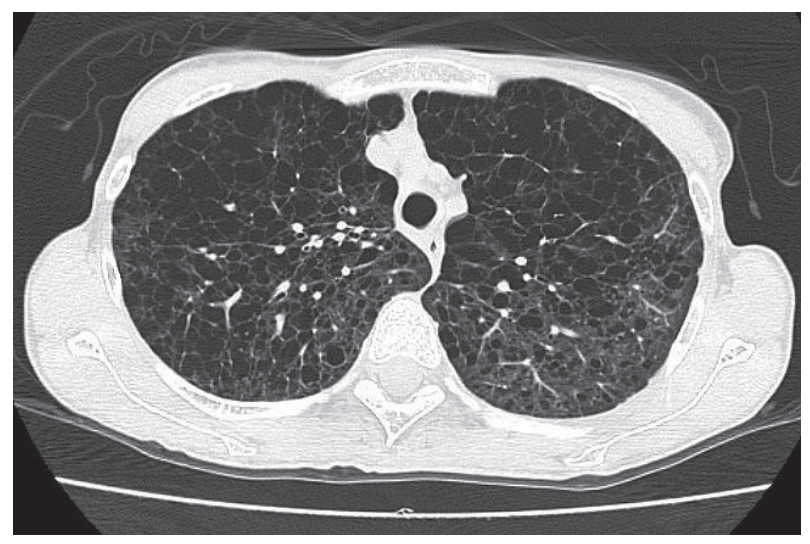

図 1 術前の胸部 CT 検査

両側の肺野全体に著明な気腫性変化を認める.

$1 \mathrm{mg}$ ，ロクロニウム $50 \mathrm{mg}$ を投与した。 $35 \mathrm{Fr}$ 左気管 支用二腔チューブ〔ポーテックス・ブルーライン気 管支内チューブ(スミスメディカル・ジャパン，東 京)」を挿管し，気管支鏡で位置を確認した。麻酔 導入後に, 右内頝静脈から肺動脈カテーテル〔スワ ンガンツ・サーモダイリューション・カテーテル (CCO/CEDV) (エドワーズライフサイエンス社, 米 国)]を留置し, 経食道心エコープローベを挿入した。 麻酔維持は，プロポフォール $3 \mathrm{mg} / \mathrm{kg} /$ 時とレミ フェンタニル $0.1 \mu \mathrm{g} / \mathrm{kg}$ / 分の持続投与による全静 脈麻酔で行った。麻酔導入後のバイタルサインは, 心拍数 (heart rate: HR) 95/分, 血圧 (blood pressure : BP) 95/59mmHg, PAP $37 / 13 \mathrm{mmHg}$ (平均肺 動脈圧 $18 \mathrm{mmHg}$ ), $\mathrm{SpO}_{2} 100 \%$ (吸入気酸素濃度 $\mathrm{FIO}_{2}$ 0.4) と, 著しい肺高血圧は認めず，呼吸循環動態は 安定していた。呼吸器設定は従圧式人工呼吸で, 吸 気压 $15 \mathrm{cmH}_{2} \mathrm{O}, \mathrm{PEEP} 4 \mathrm{cmH}_{2} \mathrm{O}$, 呼吸回数 (respiratory rate:RR)8回/分で, 1 回換気量(tidal volume : TV) 350 370mL, 呼気終末二酸化炭素濃度 $\left(\mathrm{EtCO}_{2}\right)$ は $42 \sim 44 \mathrm{mmHg}$ であった。麻酔導入後にセフォチ アム $0.5 \mathrm{~g}$ を生理食塩水 $20 \mathrm{~mL}$ に溶解して緩徐に静注 したところ, 投与開始 3 分後から TVが $135 \mathrm{~mL}$ 急 激に低下し, カプノグラム波形が右肩上がりに変化 した. 手動換気に変更しても換気は困難で, 聴診で
は両肺の呼吸音を聴取できなかった。このとき， HR 93 回/分, BP 86/55mmHg, PAP 63/36mmHg と，頻脈はなく，体血圧の低下はごくわずかであっ たが，PAPは急激に上昇していた(図2).

急激な換気困難の原因として，気管チューブの閉 塞や位置異常，気胸を疑ったが，気管支ファイバー 検査を施行して気管チューブの閉塞や位置異常は認 めなかった。胸部X線を撮影し，気胸も認めなか つたため，換気困難は気管支痤攣によるものと考え た。急性発症の換気困難の鑑別として，喘息による 気管支疰攣の可能性は否定できなかったが，発症前 に麻酔深度を変更したり体位変換や吸痰などの物理 的刺激を与えたりはしていなかった。気管支拡張作 用を期待してセボフルランを投与したが呼吸症状改 善効果はなかった。また，PAP上昇に対して一酸 化窒素も投与したが，PAPは低下しなかった。

明らかな皮疹は認めなかったが抗菌薬投与直後の 気管支痤攣であったことから，アナフィラキシーに 伴う気管支痤攣を疑つた。アドレナリン $50 \mu \mathrm{g}$ を静 脈投与したところ，速やかに換気が改善し，右肩上 がりであった $\mathrm{EtCO}_{2}$ 波形は台形になり，両肺の呼吸 音も聴取できた。TVは $240 \mathrm{~mL}$ まで改善した。聴診 でwheezesを認めたため，アドレナリンを追加投与 したところ, wheezesは完全に消失し，TVは330mL と換気異常が発生する前と同程度まで改善した。換 気状態が改善すると同時に, BP 115/63mmHg, PAP $37 / 19 \mathrm{mmHg}$ と PAPは速やかに低下した。 その後 は換気の異常やPAPの上昇をきたすことなく手術 を終了し，集中治療室へ入室した。

\section{III 考 察}

本症例では，急な換気困難が生じた直後にPAP の急激な上昇を認め, 換気困難が改善すると，それ に伴いPAPが低下することを経時的に観察した。

周術期にPAP 上昇をきたす原因としては，高二 酸化炭素血症・アシドーシス, 低酸素血症, 交感神 経過緊張，陽圧換気・高プラトー圧，プロタミン投 


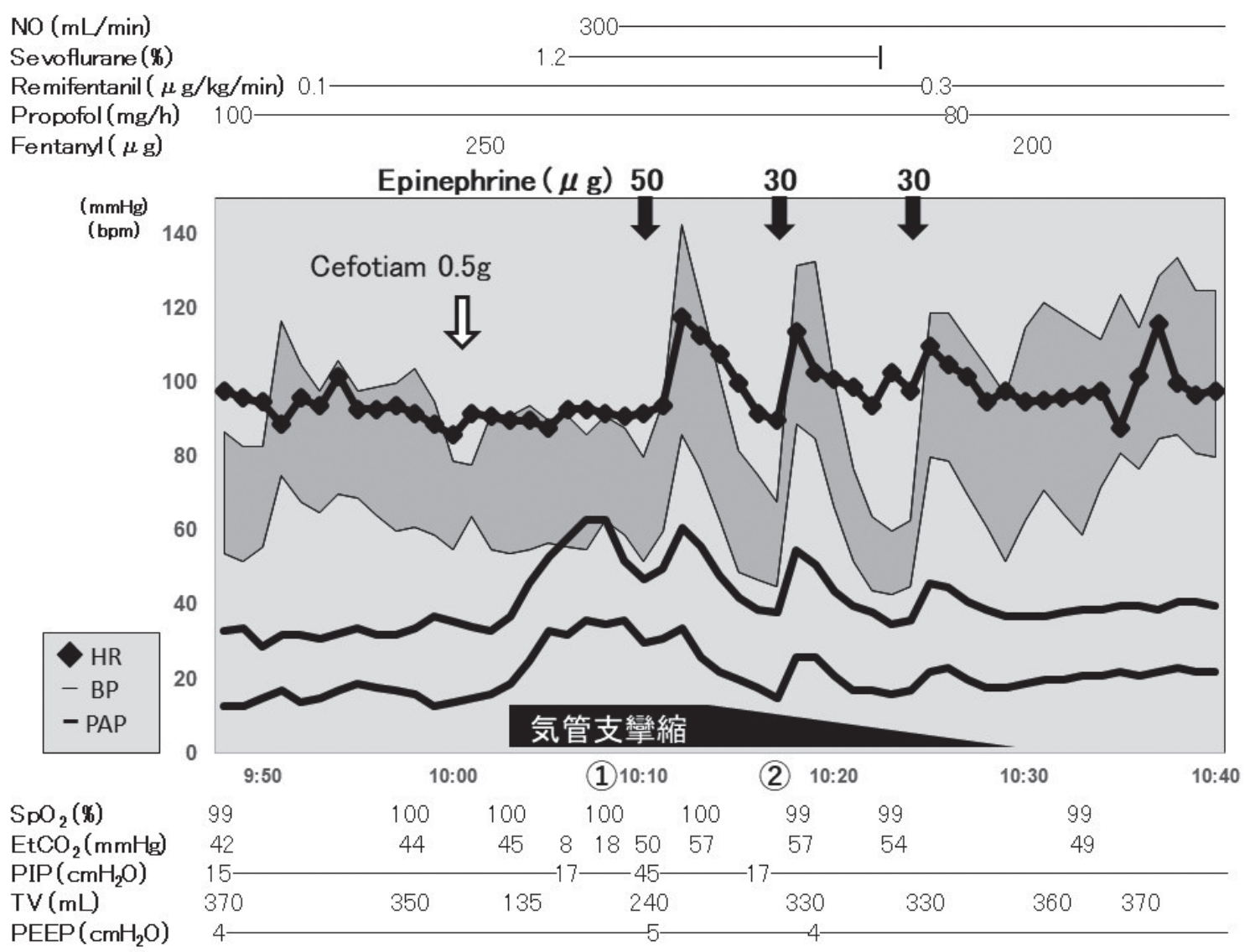

図2 麻酔経過

与, エンドトキシン・血管内皮障害, 肺血栓・塞栓 などが挙げられる ${ }^{2)}$.

本症例での動脈血液ガス分析をみると，麻酔導入 後の安定時は $\mathrm{PaCO}_{2} 47 \mathrm{mmHg}$, 換気異常の際には $\mathrm{PaCO}_{2} 56.6 \mathrm{mmHg}$ と上昇していたが，上昇の程度 は大きくなく, 高二酸化炭素血症のみでこれほど著 明な PAP上昇をきたすとは考えにくかった(表1). 陽圧換気の影響も考えられたが，従圧式人工呼吸で 吸気圧は $17 \mathrm{cmH}_{2} \mathrm{O}$ であり，高プラトー圧という設 定ではないと考える. 換気困難中も $\mathrm{PaO}_{2} 213 \mathrm{mmHg}$ $\left(\mathrm{FIO}_{2} 1.0\right)$ であり，低酸素血症は認めなかった。低 酸素血症や低血圧を認女なかったことや，換気困難 もアドレナリンで速やかに改善したことから肺塞栓 についても否定的と考えた。症状改善後の経食道心 エコーでも右心負荷所見や肺動脈内に血栓は認めな
かつた。

抗菌薬で皮疹の既往があること，抗菌薬投与直後 の気管支痙攣症状であること，また上記のような他 のPAPを上昇させる鑑別が否定的であることから， 本症例の PAP 上昇はアナフィラキシーによるもの だった可能性が考えられる。本症例では頻脈・低血 圧といった循環症状や膨疹などの皮膚症状は認めて おらず，典型的なアナフィラキシーとはいえない。 また，発症時の血中ヒスタミン・トリプターゼ測定 は休日の緊急手術であったため対応が困難であった ことや，保険適応外の検査であることから測定がで きていない.アレルゲン同定については，パッチテ ストや皮内テストなどを行うことによる気管支疷攣 再発の危険性や，移植後に投与する免疫抑制剂によ り検査結果が影響を受けることを考慮し施行しなか 
表 1 麻酔中の動脈血液ガス分析の推移

\begin{tabular}{|c|c|c|c|}
\hline 動脈血液ガス分析 & 麻酔導入後 & (1) & (2) \\
\hline $\mathrm{FIO}_{2}$ & 1.0 & 1.0 & 1.0 \\
\hline $\mathrm{pH}$ & 7.393 & 7.344 & 7.329 \\
\hline $\mathrm{PaCO}_{2}(\mathrm{mmHg})$ & 47.0 & 53.3 & 56.6 \\
\hline $\mathrm{PaO}_{2}(\mathrm{mmHg})$ & 265 & 213 & 356 \\
\hline $\mathrm{HCO}_{3}{ }^{-}(\mathrm{mmol} / \mathrm{L})$ & 28.1 & 28.2 & 28.2 \\
\hline
\end{tabular}

つたことから，アナフィラキシーの確定診断には至 っていない.しかしながら，急激で重篤なアナフィ ラキシーでは皮膚症状が出現する前に循環虚脱や呼 吸困難となることもあり，皮膚所見がないことがア ナフィラキシーの否定にはならない ${ }^{3)}$. また, 過去 の報告では全身麻酔中のアナフィラキシーにおい て，気管支痤攣症状のみを呈した症例は $2.9 \sim 3.1$ $\%^{4), 5)}$ と報告されており, 本症例も気管支痓攣のみ を呈するアナフィラキシーであった可能性が考えら れた。

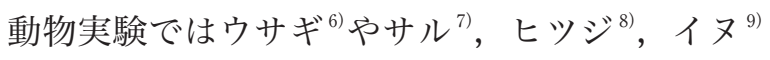
などで，アナフィラキシーの際にPAP・肺血管抵 抗が上昇することが報告されている。 マウスを用い た動物実験では，アナフィラキシーで放出されるメ ディエーターである血小板活性化因子(PAF)，口 イコトリエンC4(LTC4), セロトニン, ヒスタミン, プロスタグランジン D2(PGD2) を静脈投与すると， $\mathrm{PAP}$ ・肺血管抵抗の上昇を認めたという報告があ る ${ }^{10)}$. ヒトにおいても同様にこれらのメディエータ 一がPAP上昇に関与する可能性がある.

急性発症であること, wheezesを聴取したこと， アドレナリン投与で速やかに改善したことなどか ら，本症例は喘息であった可能性も否定できない. 喘息発作で死亡した患者 22 名の剖検では，肺動脈 周囲に肥満細胞の浸潤がみられたことが報告されて いる ${ }^{11)}$ 。た，喘息患者から摘出した肺組織を用い た研究では，肺動脈でのシクロオキシゲナーゼ -2 の発現が多く，プロスタグランジン $\mathrm{I}_{2}$ アナログ投与 によって血管平滑筋の弛緩が阻害されることが報告
されている ${ }^{12)}$.アナフィラキシーと同様に，喘息に おいても肥満細胞やそのメディエーターがPAP上 昇に関与している可能性がある。本症例の組織診は 無く, 本症例が喘息であるか確定は困難であるが, 術前に喘息発作の既往もないことから，その可能性 は低いと考えられた。

LAM は喘息様の閉塞性換気障害をきたす疾患で あり，重症例では二次性肺高血圧症を呈することも ある。また，LAMでは運動時に肺高血压を呈する ことが報告されており，その機序として低酸素血症 による肺血管抵抗上昇が考えられている ${ }^{13)}$. 本症例 では麻酔導入後の平均肺動脈圧は $17 \mathrm{mmHg}$ と高く はなかった。また，術中の動脈血液ガス分析では低 酸素血症は認めておらず，LAM そのものが肺高血 圧の原因であった可能性は低いと考える。

\section{まとめ}

本症例では，抗菌薬投与直後に急激な換気困難が 発症した際のPAPの変動を経時的に観察すること ができた。PAPは換気困難となった際に急激に上 昇し，アドレナリン投与により換気が改善すると PAPも迅速に低下した。本症例の経過から，アナ フィラキシーにおいて急激に気管支痤攣が生じた際 には, 同時に肺高血圧を呈している可能性が示唆さ れた。

本稿の要旨は, 日本麻酔科学会中国・四国支部第 55 回学術集会 (2018 年，松山市)および第 1 回周術期 アナフィラキシー研究会 (2018年，北九州市)にて発 
表した。

本症例報告にあたつては患者の承諾を得ており， 当院の発表規定に則って報告を行っている.

\section{参考文献}

1）高澤知規：手術室発症のアナフィラキシーショック. 日本臨床麻酔学会誌 $39 ： 408-414,2019$

2) Price LC, Wort SJ, Finney SJ, et al. : Pulmonary vascular and right ventricular dysfunction in adult critical care : current and emerging options for management: a systematic literature review. Crit Care 14 : R169, 2010

3）光畑裕正：全身麻酔中のアナフィラキシー。 日本臨床 麻醉学会誌 $32: 479-487,2012$

4) Fisher MM, Baldo BA : The incidence and clinical features of anaphylactic reactions during anesthesia in Australia. Ann Fr Anesth Reanim 12 : 97-104, 1993

5) Laxenaire MC, Mertes PM ; Groupe d'Etudes des Réactions Anaphylactoïdes Peranesthésiques : Anaphylaxis during anaesthesia. Results of a two-year survey in France. Br J Anaesth 87 : 549-558, 2001

6) Halonen M, Fisher HK, Blair C, et al. : IgE-induced respiratory and circulatory changes during systemic anaphylaxis in the rabbit. Am Rev Respir Dis 114 : 961-970, 1976

7) Smedegård G, Revenäs B, Lundberg C, et al. : Ana- phylactic shock in monkeys passively sensitized with human reaginic serum. I. Hemodynamics and cardiac performance. Acta Physiol Scand 111 : 239-247, 1981

8) Morel DR, Skoskiewicz M, Robinson DR, et al. : Leukotrienes, thromboxane A2, and prostaglandins during systemic anaphylaxis in sheep. Am J Physiol 261 : H782-H792, 1991

9) Mink SN, Becker A, Unruh H, et al. : Effects of anaphylaxis mediators on partitioned pulmonary vascular resistance during ragweed shock in dogs. J Appl Physiol $84:$ 782-790, 1998

10) Wang M, Shibamoto T, Kuda Y, et al. : The responses of pulmonary and systemic circulation and airway to anaphylactic mediators in anesthetized BALB/c mice. Life Sci 147 : 77-84, 2016

11) Shiang $C$, Mauad $T$, Senhorini A, et al. : Pulmonary periarterial inflammation in fatal asthma. Clin Exp Allergy 39 : 1499-1507, 2009

12) Foudi N, Badi A, Amrane M, et al. : Asthma causes inflammation of human pulmonary arteries and decreases vasodilatation induced by prostaglandin $\mathrm{I}_{2}$ analogs. J Asthma 54 : 1012-1018, 2017

13) Sonaglioni A, Baravelli M, Cassandro R, et al. : Hemodynamic Mechanisms of Exercise-Induced Pulmonary Hypertension in Patients with Lymphangioleiomyomatosis: The Role of Exercise Stress Echocardiography. J Am Soc Echocardiogr 31 : 888-901, 2018 


\title{
A Case of Lymphangioleiomyomatosis with Bronchospasm and Pulmonary Hypertension Correlated with Drug-induced Anaphylaxis during General Anesthesia
}

\author{
Shohei MYOGA*1, Yukiko HIKASA*2, Shuji OKAHARA*1, \\ Hirokazu KAWASE*2, Motomu KOBAYASHI ${ }^{* 1}$, Hiroshi MORIMATSU*1 \\ ${ }^{* 1}$ Department of Anesthesiology and Resuscitology, Okayama University Hospital \\ ${ }^{* 2}$ Department of Intensive Care, Okayama University Hospital
}

Pulmonary artery pressure and pulmonary vascular resistance have been reported to be elevated during anaphylaxis in animal model studies, but little is known about changes in pulmonary artery pressure during anaphylaxis in human. We report a case of lymphangioleiomyomatosis with bronchospasm and pulmonary hypertension correlated with drug-induced anaphylaxis during general anesthesia.

A 49-year-old woman who was diagnosed with pulmonary lymphangioleiomyomatosis was scheduled for bilateral lung transplantation. After anesthetic induction and pulmonary catheter insertion, cefotiam was infused slowly. Following infusion, peak inspiratory pressure rose, and tidal volume immediately dropped sharply. At the same time, pulmonary artery pressure rose. We assumed that bronchospasm had occurred due to drug-induced anaphylaxis. Epinephrine administration immediately improved bronchospasm and pulmonary hypertension.

Key Words : General anesthesia, Anaphylaxis, Bronchospasm, Pulmonary artery hypertension

The Journal of Japan Society for Clinical Anesthesia Vol.40 No.3, 2020 